\title{
Linking Social Values of Wild Reindeer to Planning and Management Options in Southern Norway
}

\author{
Bjørn P. Kaltenborn, ${ }^{1,2}$ Mehmet Mehmetoglu ${ }^{3}$ and Vegard Gundersen ${ }^{1}$
}

(Received 30 November 2015; accepted in revised form 25 November 2016)

\begin{abstract}
Norway is home to the last remaining populations of wild mountain reindeer (Rangifer tarandus tarandus) in Europe. Concerns over anthropogenic and natural drivers have led to change in the management regime from a population-based model to an area-based model. More complex management goals, increasing involvement of stakeholders, and larger management units call for improved knowledge about reindeer-related values. We examined the responses of 1000 respondents to 39 statements of attitudes and values associated with wild reindeer presence and the management situation in two reindeer regions of southern Norway. We used a partial least-squares path modeling approach to examine the nexus between the attraction of wild reindeer, sustainability concerns, utilitarian and non-utilitarian values, conflicts, and attitudes toward hunting. The results show that local concepts of the sustainability of reindeer are based on opinions about the ecological requirements as well as the roles reindeer can play in the social and economic development of the communities. The attraction of reindeer is a function of consumptive as well as non-consumptive objectives. Segments of the community with different consumptive orientations can share ideas about the attraction of reindeer, but diverge in their interpretation of the sustainability of the species. Improved knowledge about the diversity and complexity of value orientations associated with wild reindeer can be a useful tool for developing multi-objective management frameworks with a diversity of stakeholders who may share similar values and interests, although they have different experience and knowledge bases.
\end{abstract}

Key words: wild reindeer; Norway; management; values; community development

RÉSUMÉ. Les toutes dernières populations de rennes sauvages des montagnes (Rangifer tarandus tarandus) de l'Europe se trouvent en Norvège. Des préoccupations sur le plan des motifs anthropiques et des motifs naturels ont donné lieu à la modification du régime de gestion, qui est passé d'un modèle axé sur la population à un modèle axé sur la région. En raison des objectifs de gestion plus complexes, de l'influence accrue des parties prenantes et de secteurs de gestion plus grands, il y a lieu de se doter de meilleures connaissances au sujet des valeurs liées aux rennes. Nous avons examiné les réponses de 1000 répondants à 39 énoncés relatifs aux attitudes et aux valeurs liées à la présence des rennes sauvages et à la situation de la gestion dans deux régions où évoluent les rennes, dans le sud de la Norvège. Nous avons fait la modélisation du parcours au moyen de la régression partielle par les moindres carrés dans le but d'examiner la connexion entre l'attraction du renne sauvage, les inquiétudes en matière de durabilité, les valeurs utilitaires et non utilitaires, les conflits et les attitudes vis-à-vis de la chasse. Selon les résultats, les concepts locaux de la durabilité du renne reposent sur des opinions au sujet des exigences écologiques ainsi que sur les rôles que peuvent jouer les rennes dans le développement social et économique des collectivités. L'attraction du renne dépend des objectifs de consommation et des objectifs de non-consommation. Les segments de la collectivité ayant des orientations de consommation différentes peuvent partager des idées au sujet de l'attraction du renne, mais leur interprétation de la durabilité de l'espèce diverge. Il serait utile de posséder de meilleures connaissances au sujet de la diversité et de la complexité des orientations de la valeur liées au renne sauvage, car cela pourrait permettre d'élaborer des cadres de gestion à maints objectifs avec une diversité de parties prenantes susceptibles d'avoir des valeurs et des intérêts semblables, bien que leurs connaissances et leurs expériences diffèrent.

Mots clés : renne sauvage; Norvège; gestion; valeurs; développement communautaire

Traduit pour la revue Arctic par Nicole Giguère.

\section{INTRODUCTION}

Reindeer (Rangifer tarandus sp.) is a keystone species in Arctic and Subarctic ecosystems across the circumpolar North (Kofinas et al., 2000; Castro et al., 2016). Wild reindeer and caribou inhabit large regions that feel the impacts of anthropogenic drivers, such as expanding resource development through mining, agriculture, forestry, tourism, energy development, roads, and settlements, as well as natural drivers like climate change. Fragmentation and reduction of the quality of habitats affect distribution, population dynamics, and the general

\footnotetext{
${ }^{1}$ Norwegian Institute for Nature Research, Fakkelgården, Storhove, N-2624 Lillehammer, Norway

${ }^{2}$ Corresponding author: bjorn.kaltenborn@nina.no

${ }^{3}$ Norwegian University of Science and Technology, Department of Psychology, Høgskoleringen 1, 7491 Trondheim, Norway

(C) The Arctic Institute of North America
} 
condition of populations (Vistnes and Nellemann, 2008; Strand et al., 2010; Panzacchi et al., 2013). Some researchers argue that along with climate change and anthropogenic disturbance, there has been a steady decline of the main circumpolar reindeer populations (Vors and Boyce, 2009; Hansen et al., 2011; Hansen and Grøtan, 2015), though the global status of these trends is not certain. Intensive reindeer husbandry since the 16th century has influenced the number of wild herds through extensive displacement of wild animals by domestic herds (Baskin, 2005). From a long-term perspective, the decline of the wild reindeer population has been particularly dramatic in Europe, where its main distribution is currently restricted to 23 units in the mountain areas of southern Norway, which contain altogether 30000 wild reindeer (Røed et al., 2014).

Herds of wild reindeer use extensive Arctic and Subarctic regions (Vistnes and Nellemann, 2008). Some of these herds are still migratory. Through time, these nomads of the North have provided sustenance and livelihoods for a great many people in the Arctic and boreal regions, and both wild and domesticated reindeer figure prominently in the socio-cultural contexts, narratives, and belief systems of northern cultures (Klokov, 1997; Sjoholm, 2007; Stammler, 2007; Sommerseth, 2011; Castro et al., 2016). Reindeer husbandry has also proved adaptive to changes in society, but simultaneously quite vulnerable to changing land uses, loss of available habitat, and increasing regulation of reindeer management (Bostedt et al., 2003; Sandström et al., 2006; Brännlund and Axelsen, 2011).

A general trend in contemporary ungulate management is the gradual movement from more or less expertdriven, population-based management of herds and subpopulations towards wildlife management that merges with multiple-use planning, covering larger areas and regions. This change brings more stakeholders and different forms of knowledge into policy and management processes. The line between conservation and utilization is often blurred and the distinctions are multifaceted, requiring policy and approaches that are open to negotiations and articulation of more complex management goals. The values of reindeer and caribou are not always evident in the context of modern resource development in the North. Research that identifies reindeer-related social values is needed as a contribution to more ecosystem-based approaches. In particular, we see the need to examine reindeer as representing diverse values with the potential of providing a range of benefits in the socio-political landscape of northern resource development. This view extends beyond the consumptive vs. nonconsumptive dichotomy and calls for elaborating marketand non-market-mediated values related to reindeer.

In this paper, we explore how wildlife (reindeer) value orientations are associated with preferences and attitudes regarding both management goals and the roles that wild reindeer play in the rural communities in the Rondane and Setesdal mountain regions of southern Norway. We examine three research questions that we consider salient for improving stakeholder involvement in wild reindeer management and planning: 1) What are the key value dimensions attributed to wild reindeer by local communities adjacent to wild reindeer ranges? 2) How are these value dimensions interrelated? and 3) What types of values and socio-cultural constructs are critical to include in future wild reindeer planning and management?

\section{BACKGROUND}

\section{More Stakeholders on the Management Scene}

During the 1990s and early 2000s, rapidly increasing tourism, the construction of second homes, and energy development and associated infrastructure caused national and international concern over the status and potentially inadequate protection of Europe's last wild reindeer populations (Andersen and Hustad, 2004; Vistnes et al., 2004). Once large and contiguous populations of wild reindeer gradually fragmented into a number of smaller populations as a result of human impacts, especially throughout the 20th century. Currently, 23 subpopulations are spread throughout the mountain ranges of southern Norway, and exchange between the different groups is limited (Panzacchi et al., 2013). Since the 16th century, many of these herds have been in contact with and extensively displaced by domesticated reindeer. Herds range from genetically pure native populations to populations in which considerable intermixing with domesticated herds has occurred (Røed et al., 2014). For example, the Rondane herds are considered to have a purer wild origin than the other herds. Here, we focus on wild reindeer. Although the genetics, morphology, and range requirements of wild and domesticated reindeer are quite similar, their relationships with humans differ significantly. Domesticated reindeer are usually herded, easily watched, and slaughtered in large numbers after being rounded up in pens in the fall. Their wild counterparts are more elusive: herds change their behavior and composition through the seasons, and hunters frequently face a strenuous exercise of tracking, spotting, and catching animals in remote parts of the mountains. Because of political priorities and the international responsibility for conservation, wild and domesticated reindeer populations are managed quite differently (Andersen and Hustad, 2004).

Wild reindeer management has a long history rife with population fluctuations due to hunting pressure, land use changes, human disturbance, and inadequate population inventories (Nellemann et al., 2003). Conflict over these issues eventually motivated a refined management regime. From a series of stakeholder consultations and policy development, a new management framework materialized in 2005 under the Norwegian acronym VISA ('Wild reindeer and society'). The new framework focuses on management of larger units of reindeer habitat, more stakeholder involvement, intersectoral cooperation, and enhancement of non-consumptive values of reindeer 
(Andersen and Hustad, 2004; Miliøverndepartementet, 2005). As an outcome of this process, Norway is currently implementing a series of regional-level management plans for wild reindeer with the explicit, but broad and potentially contrary, objectives of securing conservation as well as rural development (Hongslo and Lundberg, 2012). Currently, nine regional-level plans have been completed. These are designed as an overall framework based on general objectives and zonation principles. What remains now, and where many of the real battles will unfold in the implementation phase, is the operationalization through action plans and concrete land use decisions.

In sum, the Norwegian management model for wild reindeer is evolving, from an adaptive and expert-driven approach with the chief objective of maintaining harvestable populations at desired densities (Bråtå, 2003) by regulating hunting, to broader plans for land use that incorporate a range of stakeholder interests (Miljøverndepartementet, 2005). Management based on this model will involve local communities and other land use interests to a greater extent than in the past. The approach activates a much-needed discussion about how to balance the interests and values associated with wild reindeer with other land use goals and rights in the mountain ranges.

\section{Wildlife Value Orientations}

Effective wildlife management policies need reliable information about stakeholders' attitudes toward different kinds of wildlife use. Quite often, lay peoples' values, attitudes, and preferences are at odds with those of experts and decision makers. At any rate, public values and perceptions linked to wildlife are always embedded in a larger complex of cognition about nature (Buijs, 2009). The concept of wildlife value orientations has been used extensively to measure human relationships with wildlife. The theoretical basis of the construct is a psychological hierarchical model of values, attitudes, and behavior (Ajzen, 2001, 2005). Values refer to fundamental cognitions that serve as a foundation for attitudes and beliefs (Rokeach, 1973; Homer and Kahle, 1988; Schwartz, 1992). Wildlife value orientations are seen as specific expressions about the importance and meaning of wildlife (Fulton et al., 1996; Deruiter and Donnelly, 2002). In a cognitive hierarchy, wildlife value orientations build on a structure of fundamental life values and broader environmental attitudes or worldviews. Several studies have shown wildlife value orientations to be strongly predictive of attitudes toward fish and wildlife issues (Dougherty et al., 2003; Manfredo, 2008). Furthermore, since the wildlife value orientations integrate ideology in order to understand the meaning that people assign to values, the concept is applicable to cross-cultural contexts, provided that the specific questions are properly contextualized (Teel et al., 2007; Manfredo, 2008). The cross-cultural applicability of wildlife value orientations is evidenced through the use of the construct in widely different cultures (e.g., Raadik and
Cottrell, 2007; Tanakanjana and Saranet, 2007; Zinn and Shen, 2007; Vaske et al., 2011).

Values can exist at different levels of specificity, and some studies have identified the higher-order value orientations of domination (reflecting an ideological view of human mastery) and mutualism (reflecting a more egalitarian ideology) (Manfredo and Dayer, 2004; Manfredo et al., 2009). Embedded in this higher-order structure, typical basic wildlife beliefs identified in different settings concern wildlife use, rights associated with wildlife and human use, experience, existence and bequest values (the ability to enjoy wildlife and pass on knowledge through heritage and education), pro-hunting vs. anti-hunting attitudes, environmentalism, safety, rational or scientific approaches, religion and spirituality, and respect (Fulton et al., 1996; Dayer et al., 2007; Jacobs, 2007). Relationships with wildlife can comprise one or all of these key dimensions, and they are dynamic, like all social values, in the sense that their interpretation and relative importance can change over time and are affected by surrounding societal processes (e.g., Manfredo et al., 2009).

\section{METHODS}

\section{Study Area and Sample}

The study area covers Rondane and Setesdal, two mountain regions in southern Norway, where new regional plans for wild reindeer management are now being implemented (Fig. 1) (Miljøverndepartementet, 2005; Hongslo and Lundberg, 2012; Kaltenborn et al., 2014). Both regions include extensive reindeer habitat, rugged terrain, and a range of competing land use interests (grazing, forestry, tourism, second homes). We constructed a sample of residents from both regions weighted by gender and age to be representative of the population in the 10 municipalities in these regions and estimated that a sample size of 500 respondents in each region would be needed to conduct multivariate analyses on selected variables. We collected data through a structured questionnaire administered by a data collection agency (NORSTAT, www.norstat.no). Interviewers used systematic random sampling in which the sample structure was defined by the socio-demographic structure of the population in the study area. Data collection proceeded until the predefined net sample of 1000 respondents was reached.

We examined the three research questions through three batteries of statements. We formulated seven statements representing potential management objectives for wild reindeer in a larger land use-planning context (Table 1). These statements covered consumptive as well as nonconsumptive uses and addressed possible benefits to individuals and communities. In terms of the various roles and the importance of wild reindeer in the mountain communities, we asked respondents to state their level of agreement with nine statements that related reindeer 


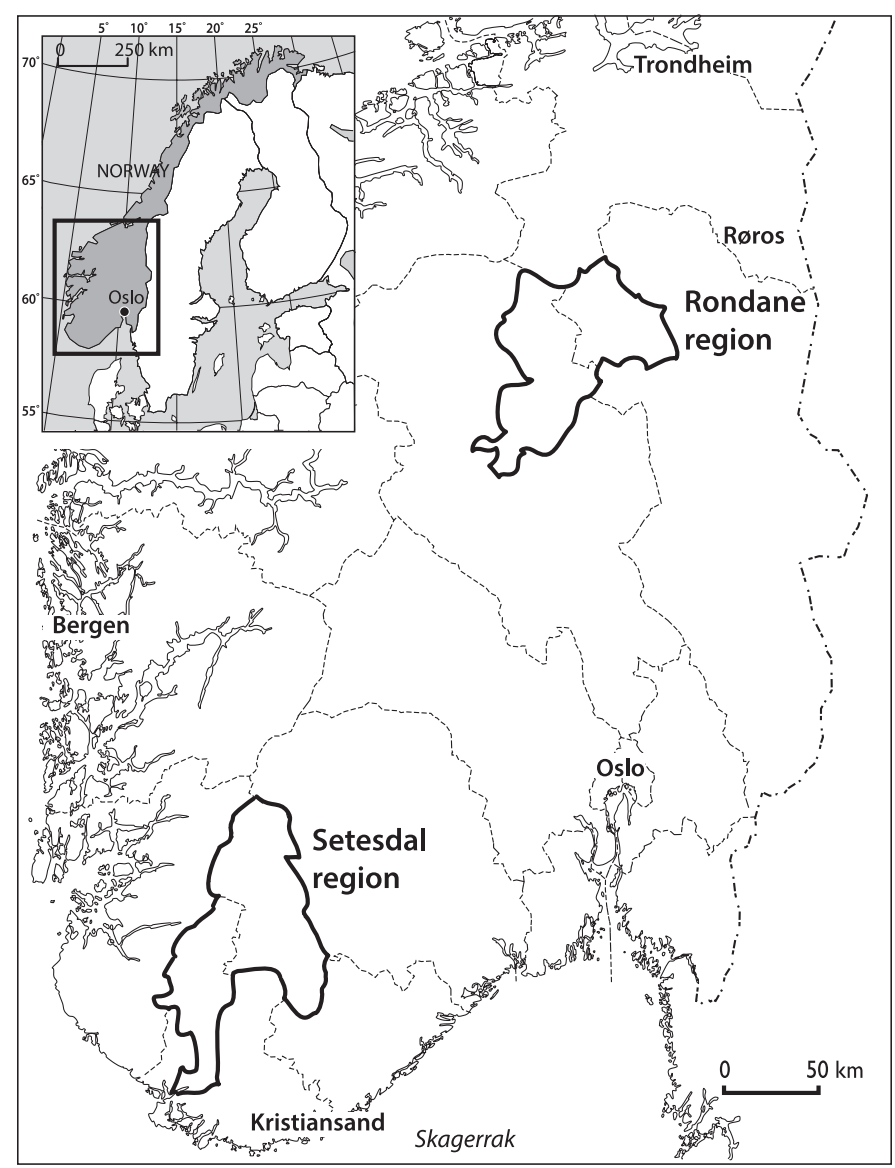

FIG. 1. Study areas in the Rondane and Setesdal wild reindeer regions of southern Norway.

to other land uses and management (Table 1). Both sets of statements were based on a combination of research literature on reindeer in Norway, studies on wildlife value orientations, and practical experience gained through stakeholder processes (Andersen and Hustad, 2004).

To examine wildlife value orientations, we formulated 23 statements contextualized to reindeer, inspired by former studies of wildlife value orientations (Fulton et al., 1996; Teel et al., 2007; Manfredo, 2008) tapping into dimensions like hunting, anti-hunting sentiments, attraction, experience, use, conflict, environmentalism and sustainability concerns (Table 2). The response format was the same for all three groups of questions, i.e., the respondents were asked their level of agreement on a scale of 1 (absolutely disagree) to 5 (absolutely agree). Wording, format, and mean scores for the three sets of questions are shown in Tables 1 and 2.

In order to be able to attribute a more general value profile to people in different segments of each community, we also included a measure of broader environmental attitudes, since for practical purposes, participatory planning and management processes need to have some basic indicators they can use to target their audiences. We employed one of the most commonly used environmental attitudes inventories, the New Environmental Paradigm (NEP) scale that measures an ecocentric to anthropocentric orientation (Dunlap et al., 2000; Dunlap and Jones, 2002). The scale comprises items that measure the so-called new ecological worldview that humans are part of nature and must exercise care and consciousness in the use of environmental resources. It contrasts this view with items that measure the traditional "dominant social paradigm" view that humans are exempt from nature and hence rule over the physical world and have the right to use the environment for their own purposes. The original scale consisted of 15 items, but multiple studies have confirmed satisfactory reliability and validity with a reduced version containing six to eight items (Dunlap, 2008; Kaltenborn et al., 2009; Hawcroft and Milfont 2010). In this study, we used a six-item scale. Wording, format, and mean scores are shown in Table 3.

\section{Data Analysis}

We ran a one-way analysis of variance (in SPSS) to test for differences between men and women, different age cohorts, and levels of education in terms of a general environmental orientation among community residents. To identify latent value-attitude constructs and their interrelationships, we took an exploratory approach through a partial least-squares path modeling (PLS-PM) of the relationships between wildlife values, attitudes toward management, and perceived importance of reindeer for communities as the data analytical procedure in this study (using XLSTAT). The partial least-squares method was chosen because the scales used in the current study are strictly speaking data-driven. PLS-PM is a preferable approach to structural equation modeling when the aim is prediction with an exploratory approach. Although PLS-PM estimates both the measurement model and the structural model simultaneously, the assessment of the estimated full model should involve a two-step process encompassing 1) the examination of the measurement model and 2) the assessment of the structural model (Henseler et al., 2009). Whereas the measurement model allows us to examine whether the constructs are measured with satisfactory accuracy, the structural model lets us assess the predictive power of the model (see Cool et al., 1989). However, the former is a prerequisite for the latter as it makes sense to evaluate the structural model only when the measurement model exhibits evidence of reliability and validity (Henseler et al., 2009).

\section{RESULTS}

\section{Resident Characteristics}

The sample consisted of 1000 participants $(50.5 \%$ men and $49.5 \%$ women) whose mean age was 47 years. Wild reindeer management was a topic of considerable interest in these mountain communities. More than half the respondents $(53 \%)$ expressed great or very great interest, 
TABLE 1. Statements about potential management objectives and the role of wild reindeer in the mountain communities presented to community respondents, who were asked to indicate to what extent they agreed with each statement. Scale of possible responses: 1 - absolutely disagree, 2 - disagree, 3 - neither agree nor disagree, 4 - agree, 5 - absolutely agree.

Potential Management Objectives

Question: Wild reindeer management needs to consider multiple interests.

What is your opinion about the following objectives for management of wild reindeer?

Mean scores

Preserve viable populations in order to maintain ecosystems/untrammeled environments in the mountains 4.20

Contribute to sustainable mountain communities 3.89

Ensure resources for hunting in order to maintain old harvesting traditions in the mountain communities 3.75

Secure wild reindeer populations as a source of experiences for nature-based tourism and recreation 3.71

Use wild reindeer to increase the public's knowledge about nature in general 3.64

Provide maximum yield of meat 2.72

Provide maximum economic yield for land owners 2.60

Role of Reindeer in Mountain Communities

Question: There are different opinions about the role of wild reindeer in the mountain communities. To what extent do you agree with the statements below?

The municipalities need to cooperate better around wild reindeer management

Disagreements over wild reindeer management create conflicts in the local communities

Wild reindeer range requirements should be superior to other land use interests in mountain regions with wild reindeer 3.41

Conservation of reindeer is more important than second-home development and tourism 3.36

Wild reindeer management should guide and set the course for development in the mountains 3.23

Wild reindeer management overshadows other important management tasks in the mountains 3.17

Rights and benefits associated with the utilization of wild reindeer are quite unequally distributed in the local communities 3.09

Wild reindeer interests and concerns obstruct other locally important commercial development

TABLE 2. Statements about wildlife value orientations presented to community respondents. Response format as in Table 1.

Question: Wild reindeer represent different kinds of values associated with the mountain environment, and there are many opinions about how we should estimate these values. To what extent do you agree with the following statements?

It is important to conserve good wild reindeer populations for posterity

Wild reindeer have the right to exist, independent of our needs

I greatly appreciate seeing wild reindeer when I travel in the mountains

It is good to know that there are wild reindeer in Norway, even though I don't have much contact with the species myself

Local management is vital for maintaining good populations of wild reindeer

Hunting enables people to experience nature in a nice way

We must manage wild reindeer so that we harvest the surplus

Wild reindeer can be harvested as long as the populations are not threatened

Good wild reindeer populations show that we take care of the mountain environment

The mountains would be poor without the wild reindeer

Wild reindeer have shaped our historical use of the mountains

I think it is important that we learn as much as possible about wild reindeer

The range requirements of reindeer are just as important as other human use of the mountains

Wild reindeer are especially well suited to provide us with more knowledge about nature in the mountains

We ought to use the wild reindeer populations to increase people's quality of life

Wild reindeer is one of the biggest attractions we have in the mountains

The fact that wild reindeer exist gives me a stronger emotional connection with the mountains

Wild reindeer have rights just as humans do

Today's wild reindeer populations are a result of successful state-level nature conservation

Hunting is the best use of the reindeer

I can appreciate that some people think that hunting offends the wild reindeer's right to live

but to $12 \%$, the topic was of no interest. Despite a high level of interest overall, people in these regions apparently do not encounter these animals too frequently: of our respondents, $83 \%$ never encountered reindeer through their work, and $31 \%$ never encountered them in their spare time. A mere $2 \%$ reported frequent contact with reindeer in their work, and $4 \%$ in their leisure time. Of those who reported contact with wild reindeer now and then, only $12 \%$ encountered them through work, but up to $52 \%$ in their spare time. About $20 \%$ of respondents were reindeer hunters.
With respect to environmental orientation, women reported a slightly more ecocentric attitude than men, and that difference was statistically significant (Table 3). The degree of environmental orientation correlated significantly with level of education, as people who had completed higher education tended to have a somewhat more ecocentric worldview than people with less education. Age had no significant effect on environmental orientation (Table 3). These results both corroborate and deviate from national figures. In our study, the mean environmental orientation 
TABLE 3. Measures of environmental orientation (New Environmental Paradigm [NEP] scale), and effects of gender, age and education. Response format as in Table 1.

\begin{tabular}{|c|c|c|c|}
\hline & Mean & SD & $\mathrm{N}$ \\
\hline \multicolumn{4}{|l|}{ NEP items } \\
\hline The balance in nature is delicate and easily upset & 3.87 & 1.07 & 995 \\
\hline Humans are severely abusing the environment & 3.43 & 1.19 & 996 \\
\hline The so-called environmental crisis facing humankind has been greatly exaggerated & 2.97 & 1.21 & 988 \\
\hline If things continue on their present course, we will soon experience a major ecological catastrophe & 3.22 & 1.23 & 991 \\
\hline Animals and plants have the same rights as humans to live on this earth & 3.83 & 1.21 & 993 \\
\hline The balance in nature is strong enough to cope with the impact of modern industrial nations & 2.63 & 1.08 & 990 \\
\hline Mean for NEP scale & 3.45 & 0.76 & 976 \\
\hline \multicolumn{4}{|l|}{ Gender } \\
\hline Men & 3.29 & 0.77 & 497 \\
\hline \multirow[t]{2}{*}{ Women } & 3.62 & 0.72 & 480 \\
\hline & $F=48.614$ & \multicolumn{2}{|c|}{ Sign. $=0.000$} \\
\hline \multicolumn{4}{|l|}{ Age (years of age) } \\
\hline Under 30 & 3.43 & 0.74 & 214 \\
\hline $30-39$ & 3.50 & 0.73 & 117 \\
\hline $40-49$ & 3.47 & 0.74 & 187 \\
\hline \multirow[t]{2}{*}{$50+$} & 3.45 & 0.79 & 458 \\
\hline & $\mathrm{F}=0.225$ & \multicolumn{2}{|c|}{ Sign. $=0.879$} \\
\hline \multicolumn{4}{|l|}{ Education (completed) } \\
\hline Primary school & 3.32 & 0.65 & 114 \\
\hline Secondary school & 3.41 & 0.76 & 249 \\
\hline Vocational training & 3.36 & 0.69 & 189 \\
\hline College/university up to 4 years & 3.52 & 0.80 & 239 \\
\hline \multirow{2}{*}{ College/university more than 4 years } & 3.62 & 0.82 & 179 \\
\hline & $\mathrm{F}=3.889$ & \multicolumn{2}{|c|}{ Sign. $=0.002$} \\
\hline
\end{tabular}

(NEP scale score) was 3.45; that is, slightly skewed towards the ecocentric part of the scale, whereas Gangaas et al. (2015) report a mean of 3.38 for the public in a nationally representative study. In our study area, women reported a more ecocentric attitude than men, whereas the opposite is the case on at the national level, although the differences are not large conceptually. Both in our study and nationally, increasing ecocentrism is associated with higher levels of education. While we found no relationship between age and degree of ecocentrism, several other studies have found that the degree of anthropocentric orientation tends to increase with age (Dunlap et al., 2000; Gangaas et al., 2015).

\section{Measurement Model}

The measurement model produced eight latent variables based on combinations of the questions about potential management objectives, roles of reindeer in the communities, and wildlife value orientations (Table 4). These variables can be interpreted as underlying attitude and value dimensions of the interlinkages between perceptions of the roles and importance of reindeer, preferred management directions, and values associated with wild reindeer. The ecocentric variable (we use italics since these are latent variables) denotes existence and bequest type values. Attraction encompasses the aesthetic and emotional appeal of wild reindeer. Anthropocentric covers attitudes toward human benefits. Against hunting signifies anti-hunting sentiments, partly on ethical grounds. Utility covers attitudes toward material and economic gain. Sustainability expresses attitudes and underlying values of longevity and nonconsumption, as well as ecosystem integrity. Resources expresses attitudes that consider wild reindeer a highly valuable resource that should be prioritized over other land uses, and Conflict covers the beliefs that wild reindeer management creates conflicts with other land uses.

Since the measurement model contained only manifest variables, we first assessed the measurement model on the basis of the size, average variance extracted (AVE), composite reliability (CR), and discriminant validity of each item loading (Liang et al., 2007). We calculated AVE by taking the average of squared standardized loadings. As shown in Table 4, AVE values exceeded the recommended level of 0.5 (Fornell and Larcker, 1981), and all CR values exceeded the suggested figure of 0.6 (Diamantopoulos and Siguaw, 2000). These findings were indicative of reliability and convergent validity. Further, as seen in Table 5, all of the AVE values were larger than the squared correlations among the latent variables in the model and thus demonstrated discriminant validity (Hair et al., 2006). In other words, the eight underlying value attitude and value dimensions based on statements about wildlife value orientations, the role of reindeer in local communities, and potential management objectives give conceptual meaning and are statistically valid. Since the measurement model showed satisfactory validity and reliability, it could be used to examine the structural part of the model, i.e., the interrelationships between these underlying dimensions (Henseler et al., 2009).

\section{Structural Model}

As the coefficient of determination $\left(r^{2}\right)$ alone cannot be used to evaluate the quality of the whole structural model (i.e., several equations) (Esposito Vinzi et al., 2010), an 
TABLE 4. Measurement model. Latent variables (in italics) and manifest variables (lower case). .

\begin{tabular}{|c|c|c|c|}
\hline Variable & $\lambda^{1}$ & $\mathrm{CR}^{1}$ & $\mathrm{AVE}^{1}$ \\
\hline Ecocentric & & 0.886 & 0.723 \\
\hline It's good to know that there are wild reindeer in Norway, even if I am not much in contact with species myself & 0.865 & & \\
\hline It's important to preserve good populations of wild reindeer for posterity & 0.860 & & \\
\hline Wild reindeer have a right to exist, independent of our needs & 0.825 & & \\
\hline Attraction & & 0.878 & 0.699 \\
\hline Wild reindeer are one of the greatest attractions we have in the mountains & 0.791 & & \\
\hline Wild reindeer are one of the main reasons I use the mountains & 0.823 & & \\
\hline The existence of wild reindeer gives me a stronger emotional attachment to the mountains & 0.892 & & \\
\hline Anthropocentric & & 0.761 & 0.512 \\
\hline We must manage wild reindeer so that we harvest the surplus & 0.738 & & \\
\hline Wild reindeer can be harvested as long as the populations are not threatened & 0.628 & & \\
\hline We should use the wild reindeer populations to increase people's quality of life & 0.773 & & \\
\hline Against hunting & & 0.802 & 0.667 \\
\hline I can understand that some people think hunting offends the wild reindeer's right to live & 0.852 & & \\
\hline Wild reindeer populations should not be regulated by hunting, but rather by natural factors like predators, disease, and access to food & 0.780 & & \\
\hline Utility & & 0.855 & 0.750 \\
\hline The goal of wild reindeer management should be to provide optimal yields of meat & 0.853 & & \\
\hline The goal of wild reindeer management should be to provide optimal economic yield to land owners & 0.879 & & \\
\hline Sustainability & & 0.833 & 0.560 \\
\hline The goal of wild reindeer management should be to secure populations as an experience resource for nature-based tourism & 0.760 & & \\
\hline The goal of wild reindeer management should be to contribute to sustainable mountain communities & 0.682 & & \\
\hline $\begin{array}{l}\text { The goal of wild reindeer management should be to preserve viable populations of wild reindeer in order to maintain mountain } \\
\text { ecosystems and untrammeled nature }\end{array}$ & 0.766 & & \\
\hline The goal of wild reindeer management should be to use wild reindeer to improve people's knowledge about nature in general & 0.780 & & \\
\hline Resources & & 0.926 & 0.807 \\
\hline Wild reindeer conservation is more important than second homes and tourism & 0.892 & & \\
\hline Wild reindeer management should set the direction for development in the mountain regions & 0.927 & & \\
\hline Wild reindeer habitat requirements should be superior to other land use interests in mountain regions with wild reindeer & 0.874 & & \\
\hline 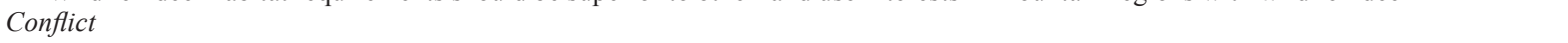 & & 0.771 & 0.636 \\
\hline Wild reindeer management overshadows other important management tasks in the mountains & 0.820 & & \\
\hline Disagreements over wild reindeer management create conflicts in the local communities & 0.774 & & \\
\hline
\end{tabular}

${ }^{1} \lambda=$ standardized loadings, $\mathrm{CR}=$ composite reliability, and AVE $=$ average variance extracted.

TABLE 5. Discriminant validity (squared correlations $<$ AVE).

\begin{tabular}{|c|c|c|c|c|c|c|c|c|}
\hline & Ecocentric & Attraction & Anthropocentric & $\begin{array}{l}\text { Against } \\
\text { hunting }\end{array}$ & Utility & Sustainability & Resources & Conflict \\
\hline Ecocentric & 1 & & & & & & & \\
\hline Attraction & 0.273 & 1 & & & & & & \\
\hline Anthropocentric & 0.146 & 0.129 & 1 & & & & & \\
\hline Against hunting & 0.036 & 0.032 & 0.000 & 1 & & & & \\
\hline Utility & 0.000 & 0.003 & 0.063 & 0.000 & 1 & & & \\
\hline Sustainability & 0.368 & 0.293 & 0.182 & 0.044 & 0.002 & 1 & & \\
\hline Resources & 0.344 & 0.342 & 0.054 & 0.068 & 0.004 & 0.350 & 1 & \\
\hline Conflict & 0.001 & 0.000 & 0.013 & 0.001 & 0.002 & 0.000 & 0.007 & 1 \\
\hline Ave & 0.723 & 0.699 & 0.512 & 0.667 & 0.750 & 0.560 & 0.807 & 0.636 \\
\hline
\end{tabular}

additional global criterion of goodness-of-fit (GoF) has been proposed by Tenenhaus et al. (2005). The intent is to account for the performance of both the measurement and the structural models (considering all of the $r^{2}$ values) with a focus on overall prediction performance of the model (Chin, 2010). Thus, GoF can be used as an index for validating the model globally (Tenenhaus et al., 2005). The GoF index is bounded between 0 and 1; models exhibiting relative GoF values equal to or higher than 0.90 can be considered good (Esposito Vinzi et al., 2010). The relative GoF value of this study's model was 0.931 , which clearly speaks in favour of the model. As a result, we could go on to examine specifically the significance and direction of the standardized path coefficients, as well as individual $r^{2}$ values (see bottom row in Table 6).

\section{Path Coefficients}

As seen in Table 5, both Sustainability and Resources have a significant positive effect on Ecocentric, whereas Utility and Conflict do not. The model explains about $48 \%$ of the variance in Ecocentric, which means that a number of factors have a greater effect on the Ecocentric value and attitude dimension than instrumental interests and perceptions of reindeer as a source of conflict. These factors include concerns and interests linked to nonconsumptive uses of reindeer, collective or communal rather than individual rights and interests, educational purposes, and the view that reindeer interests should take priority over those of other land users in planning and land use. Furthermore, apart from Conflict, all of the predictors 
TABLE 6. The structural model (standardized coefficients and standard errors).

\begin{tabular}{|c|c|c|c|c|c|c|c|c|}
\hline \multirow{2}{*}{$\begin{array}{l}\text { Endogenous: } \\
\text { Exogenous }\end{array}$} & \multicolumn{2}{|c|}{ Ecocentric } & \multicolumn{2}{|c|}{ Attraction } & \multicolumn{2}{|c|}{ Anthropocentric } & \multicolumn{2}{|c|}{ Against hunting } \\
\hline & $\beta$ & $\mathrm{SE}$ & $\beta$ & $\mathrm{SE}$ & $\beta$ & $\mathrm{SE}$ & $\beta$ & $\mathrm{SE}$ \\
\hline Utility & -0.010 & 0.023 & $0.086^{* * *}$ & 0.024 & $0.235 * * *$ & 0.027 & 0.000 & 0.031 \\
\hline Sustainability & $0.436^{* * *}$ & 0.029 & $0.302 * * *$ & 0.031 & $0.430 * * *$ & 0.035 & $0.092 *$ & 0.039 \\
\hline Resources & $0.331 * * *$ & 0.029 & $0.404 * * *$ & 0.031 & 0.018 & 0.035 & $0.207 * * *$ & 0.039 \\
\hline Conflict & 0.000 & 0.023 & 0.030 & 0.024 & $0.091 * *$ & 0.027 & 0.026 & 0.030 \\
\hline$r^{2}$ & \multicolumn{2}{|c|}{0.477} & \multicolumn{2}{|c|}{0.416} & \multicolumn{2}{|c|}{0.272} & \multicolumn{2}{|c|}{0.076} \\
\hline
\end{tabular}

$* p<.05, * * p<.01, * * * p<.001$

have a positive significant effect on Attraction, explaining in tandem about $42 \%$ of the variance on Attraction. This result means that the attraction of reindeer is linked to attitudes and values ranging from conservation of reindeer and concern for future viability of populations, to the use of reindeer for various non-consumptive purposes, to providing meat and economic income. Moreover, three of four independent variables (Utility, Sustainability and Conflict) have a significant positive effect on Anthropocentric. The model explains about $28 \%$ of the variance in Anthropocentric. This shows that the view of reindeer as primarily a resource to satisfy various human needs is significantly influenced by how people perceive the usefulness of reindeer and what they see as key reindeer roles in ecological terms, as well as in community development. Finally, only Sustainability and Resources have a significant positive effect on Against hunting. The model explains only about $8 \%$ of the variance in Against hunting. In other words, the anti-hunting view is a slightly less complex construct, primarily influenced by what people think should be the roles of reindeer in the future and what roles reindeer should play in relation to other land uses in the mountains.

\section{DISCUSSION}

Both popular and scientific literature attest to the historical and cultural significance of wild reindeer in Norway through time (Bang-Andersen, 2012). While hunting was formerly a key to survival in a demanding environment, it is currently a resource for recreational hunting, non-consumptive experiences, and cultural identity (e.g., Bye, 2009; Øian and Skogen, 2016). In this study, we saw that community residents claim great interest in wild reindeer although they do not necessarily interact extensively with them.

The results of this study showed that the community perspectives on reindeer are complex, reflecting attitudes toward sustainability, ecological requirements, and economic benefits to individuals and communities. The study also showed that the attraction of reindeer is shaped by utilitarian as well as non-use values; that is, wild reindeer are perceived as an attractive resource both by people who emphasize harvesting and consumptive use and by those who prefer to maintain the populations primarily for non-consumptive uses. In addition, segments of the local communities with different consumptive orientations may share their concepts of attraction, but differ in their interpretation or understanding of the sustainability of the species.

Wild reindeer represent both an instrumental and an emotional attachment to the mountains. The type and level of attraction are influenced by attitudes toward sustainability and are positively affected by the level of importance given to reindeer interests over alternative and competing land uses, as well as by the perceived utility of the species. Conflicts over socially significant wildlife often focus on the attraction of the species for different stakeholders (Manfredo and Dayer, 2004; Newsome et al., 2005). This study also found that attraction is a multidimensional construct: a concept that is not necessarily agreed upon across different stakeholder interests.

The more traditional conservation-type values that we identified as an ecocentric value orientation in this study were influenced by sustainability concerns different from those influencing the more anthropocentric orientation. The ecocentric orientation was more related to non-consumptive objectives. The desire of local communities to maintain viable populations of wild reindeer was rooted in concerns about local development and the educational potential of wildlife in maintaining culture and harvesting traditions, as well as in concern for the ecological requirements of reindeer. In other words, conservation-type arguments had a relatively strong basis in bequest and existence type values targeting collective or community interests (how the community, and not just individual landowners, can benefit from the reindeer in the future). Anti-hunting sentiments were also to some extent predicted by how strongly people rated the importance of non-consumptive uses of reindeer for community purposes, e.g., as an instrument in education, as an element in nature-based tourism, and for ecological dynamics. Factors like attitudes toward conflicts or use potential (meat and economic income) had no significant effect on attitudes toward hunting.

Disagreements about the importance of wild reindeer and management objectives can cause conflicts within local communities. However, our results indicated that opinions about whether reindeer habitat requirements should be given precedence over other land use interests had no 
direct bearing on the expressions about sustainability of the wild reindeer populations. Nor did consumptive objectives: that is, maximizing meat yield and economic income to landowners had no direct influence on how people understand and interpret sustainability of wild reindeer. This result suggests that the local perspective on sustainability of wild reindeer was quite diverse. It incorporated ideas about present-day use, culture, and history, as well as potential future economic benefits and needs for protection.

Numerous studies have operated with ecocentric and anthropocentric value orientations-either as parallel dimensions in environmental worldviews, or as opposite end points on a scale or continuum - as expressions of a dominantly environment-friendly orientation or a human mastery or utility orientation (e.g., for summaries, see Dunlap, 2008; Milfont and Duckitt, 2010). In this study, we saw that a simple distinction between use and preservation (for example, the common, but imprecise notion that local inhabitants prefer consumptive use to preservation) did not explain the concept of attraction of reindeer. In fact, the attraction of reindeer was influenced by what people interpreted as sustainability concerns, such as the relative importance of ecological dynamics versus human benefits, the type and level of human utility, and to what extent reindeer interests should be given priority over other land uses, as well as to what degree reindeer issues created conflicts in the local communities.

\section{Management Implications}

Wild reindeer management involves managing public values that are pulling in similar directions, since reindeer is a focal species for hunting traditions and carrier of sociocultural history in the local community. However, wild reindeer interests compete with other cornerstone activities like tourism, second-home development, agriculture, hydropower, and the sprawl of infrastructure, which have significant negative impacts on spatial use and movement of wild reindeer (Strand et al., 2010). The wildlife science perspective often contradicts lay perceptions of the wild reindeer as a robust species that is capable of inhabiting landscapes with different levels of human impact (Kaltenborn et al., 2014). Moreover, wild reindeer range requirements have repeatedly been used as a salient argument for establishing protection areas within their ranges. The cumulative effect over time is comprehensive restrictions on local exploitation of mountain resources.

The broadly composed stakeholder management planning process leading up to the current framework with regional plans identified a number of challenges and objectives (Andersen and Hustad, 2004; Hongslo and Lundberg, 2012). One major concern was the expressed need to improve dialogue and cooperation between different stakeholder interests. The preamble also identified the need to implement larger management units, increase cooperation between sectors, and enhance the cultural heritage of wild reindeer and the role of non-consumptive values in tourism and community-run enterprises. The new area management framework is ambitious and complex, and it includes far more actors than the previous populationoriented management model. Recent studies, as the plans are in the early stages of implementation, have pointed out challenging issues. The entire management process has become more politicized since multiple stakeholders technically have a say in the design of the plans and the trade-offs involved in zoning and spatially based priorities (Hongslo and Lundberg, 2012).

However, while the new plan is touted as a way of involving local communities to a much greater extent than previously, the reality is that it is mostly local mayors, i.e., politicians, who sit on the planning boards, rather than a representative sample of stakeholders. Other research also shows that the municipalities easily deviate from the intentions of the plan if reindeer conservation interests collide with other forms of resource extraction (Hongslo and Lundberg, 2012), largely because the plan has no regulatory power. Furthermore, while mechanisms for monitoring of the reindeer populations and setting harvesting quotas are well developed, few measures are in place for recording, estimating, and negotiating the range of non-consumptive and non-market-mediated values associated with wild reindeer. Cultural heritage and experiential opportunities linked to reindeer are "marketed" partly through two interpretive centers designed for this purpose and partly via the local tourism industry, but the planning framework has no agreed-upon mechanisms for evaluating trade-offs (e.g., between consumptive and non-consumptive uses) or documenting value diversity.

Yet, in this kind of framework, there should eventually be ways to measure, rank, and prioritize values linked to different resources and development options that can be spatially delimited. Naturally, such assessment implies struggling with value pluralism and value incommensurability. What we take from the study is that identifying wildlife value orientations can provide managers with a useful tool for documenting the less tangible aspects of wildlife in a way that can contribute to uniting stakeholders, rather than splitting them, in negotiating processes, since they often share values and attitudes but perhaps express them differently. For example, different stakeholders may share perceptions of the attraction and utility of wild reindeer, but disagree on the resilience of the species in the light of future human impacts. It is also a question of how to target people and get them interested in participatory processes. The results from this study show that there is considerable interest in the management of wild reindeer across the communities, that women are slightly more environmentally oriented than men, and that age does not make much difference in their views, but education does. In organizing a deliberative process, this kind of information can be vital for securing representativeness of a community, if that is a goal. 
We further argue that measuring wildlife value orientations is a way of bringing to the table insights on the many types of benefits (aesthetic, educational, spiritual, inspirational, and material) that need to be reflected in zoning and other management measures. Wise management of reindeer can also contribute to identity formation and sense of place, employment, development of social capital, maintenance of cultural heritage, and activity opportunities. A value orientation concept offers a much more nuanced way of recognizing that stakeholders can have shared values and interests in wildlife and natural resources even though their knowledge bases and experiences may be quite different (Fagerholm et al., 2012; Rodela, 2012). Constructive discussions about the importance of wild reindeer in spatial planning essentially involve trade-offs between market-mediated and non-market-mediated values. Since the first often can be measured and quantified, and the latter less so, deliberation among stakeholders is required.

\section{ACKNOWLEDGEMENT}

This study was funded by the Norwegian Research Council (grant numbers 230305 and 230370).

\section{REFERENCES}

Ajzen, I. 2001. Nature and operation of attitudes. Annual Review of Psychology 52:27-58. https://doi.org/10.1146/annurev.psych.52.1.27

- - 2005. Attitudes, personality and behavior, 2nd ed. Maidenhead, United Kingdom: Open University Press, McGraw-Hill Education.

Andersen, R., and Hustad, H., eds. 2004. Villrein and Samfunn. En veiledning til bevaring og bruk av Europas siste villreinfjell [Wild reindeer and society: A guide to conservation and use of Europe's last wild reindeer ranges]. NINA Temahefte 27. Trondheim: Norwegian Institute for Nature Research. 77 p.

Bang-Andersen, S. 2012. Colonizing contrasting landscapes. The Pioneer Coast settlement and inland utilization in southern Norway 10,000-9500 years before present. Oxford Journal of Archaeology 31(2):103-120.

https://oi.org/10.1111/j.1468-0092.2012.00381.x

Baskin, L.M. 2005. Number of wild and domestic reindeer in Russia in the late 20th century. Rangifer 25(1):51 -57. https://doi.org/10.7557/2.25.1.337

Bostedt, G., Parks, P.J., and Boman, M. 2003. Integrated natural resource management in northern Sweden: An application to forestry and reindeer husbandry. Land Economics 79(2):149-159.

https://doi.org/10.2307/3146864

Brännlund, I., and Axelsson, P. 2011. Reindeer management during the colonization of Sami lands: A long-term perspective of vulnerability and adaptation strategies. Global Environmental Change 21(3):1095-1105.

https://doi.org/10.1016/j.gloenvcha.2011.03.005
Bråtå, H.O. 2003. The Norwegian system for wild reindeer management - major development since the 19th century. Rangifer 23(Special Issue 14): 29-36. https://doi.org/10.7557/2.23.5.1650

Bujis, A.E. 2009. Lay people's images of nature: Comprehensive frameworks of values, beliefs, and value orientations. Society \& Natural Resources 22(5):417-432. https://doi.org/10.1080/08941920801901335

Bye, L.M. 2009. 'How to be a rural man': Young men's performances and negotiations of rural masculinities. Journal of Rural Studies 25(3):278-288. https://doi.org/10.1016/j.jrurstud.2009.03.002

Castro, D., Hossain, K., and Tytelman, C. 2016. Arctic ontologies: Reframing the relationship between humans and rangifer. Polar Geography 39(2):98-112.

https://doi.org/10.1080/1088937X.2016.1179352

Chin, W.W. 2010. How to write up and report PLS analyses. In: Esposito Vinzi, V.E., Chin, W.W., Henseler, J., and Wang, H., eds. Handbook of partial least squares: Concepts, methods and applications. Springer Handbooks of Computational Statistics. Heidelberg: Springer. 655-690. https://doi.org/10.1007/978-3-540-32827-8_29

Cool, K., Dierickx, I., and Jemison, D. 1989. Business strategy, market structure and risk-return relationships: A structural approach. Strategic Management Journal 10(6):507-522. https://doi.org/10.1002/smj.4250100602

Dayer, A.A., Stinchfield, H.M., and Manfredo. M.J. 2007. Stories about wildlife: Developing an instrument for identifying wildlife value orientations cross culturally. Human Dimensions of Wildlife 12(5):307-315. https://doi.org/10.1080/10871200701555410

Deruiter, D.S., and Donnelly, M.P. 2002. A qualitative approach to measuring determinants of wildlife value orientations. Human Dimensions of Wildlife 7(4):251 - 271.

https://doi.org/10.1080/10871200214754

Diamantopoulos, A., and Siguaw, J.A. 2000. Introducing LISREL. London: Sage. https://doi.org/10.4135/9781849209359

Dougherty, E.M., Fulton, D.C., and Anderson, D.H. 2003. The influence of gender on the relationship between wildlife value orientations, beliefs, and the acceptability of lethal deer control in Cuyahoga Valley National Park. Society \& Natural Resources 16(7):603-623. https://doi.org/10.1080/08941920309187

Dunlap, R.E. 2008. The New Environmental Paradigm scale: From marginality to worldwide use. Journal of Environmental Education 40(1):3-18. https://doi.org/10.3200/JOEE.40.1.3-18

Dunlap, R.E., and Jones, R.E. 2002. Environmental concern: Conceptual and measurement issues. In: Dunlap, R.E., and Michelson, W., eds. Handbook of environmental sociology. Westport, Connecticut: Greenwood Press. 482-524.

Dunlap, R.E., Van Liere, K.D., Mertig, A.G., and Jones, R.E. 2000. Measuring endorsement of the New Ecological Paradigm: A revised NEP scale. Journal of Social Issues 56(3):425-442. https://doi.org/10.1111/0022-4537.00176 
Esposito Vinzi, V., Trinchera, L., and Amato, S. 2010. PLS path modeling: From foundations to recent developments and open issues for model assessment and improvement. In: Esposito Vinzi, V.E., Chin, W.W., Henseler, J., and Wang, H., eds. Handbook of partial least squares: Concepts, methods and applications. Springer Handbooks of Computational Statistics. Heidelberg: Springer. 47-82.

https://doi.org/10.1007/978-3-540-32827-8_3

Fagerholm, N., Käyhkö, N., Ndumbaro, F., and Khamis, M. 2012. Community stakeholders' knowledge in landscape assessments - Mapping indicators for landscape services. Ecological Indicators 18:421 - 433.

https://doi.org/10.1016/j.ecolind.2011.12.004

Fornell, C., and Larcker, D.F. 1981. Evaluating structural equation models with unobservable variables and measurement error. Journal of Marketing Research 18(1):39-50. https://doi.org/10.2307/3151312

Fulton, D.C., Manfredo, M.J., and Lipscomb, J. 1996. Wildlife value orientations: A conceptual and measurement approach. Human Dimensions of Wildlife 1(2):22 - 47. https://doi.org/10.1080/10871209609359060

Gangaas, K.E., Kaltenborn, B.P., and Andreassen, H.P. 2015. Environmental attitudes associated with large-scale cultural differences, not local environmental conflicts. Environmental Conservation 42(1):41-50.

https://doi.org/10.1017/S0376892914000125

Hair, J.F., Black, B., Babin, B., Anderson, R.E., and Tatham, R.L., eds. 2006. Multivariate data analysis, 6th ed. New Jersey: Prentice Hall.

Hansen, B.B., and Grøtan, V. 2015. Global declines of caribou and reindeer. In: Book of Abstracts, $14^{\text {th }}$ International Arctic Ungulate Conference, 17-21 August 2015, Røros, Norway. 30.

Hansen, B.B, Aanes, R., Herfindal, I., Kohler, J., and Sæther, B.-E. 2011. Climate, icing, and wild Arctic reindeer: Past relationships and future prospects. Ecology 92(10):1917-1923. https://doi.org/10.1890/11-0095.1

Hawcroft, L.J., and Milfont, T.L. 2010. The use (and abuse) of the New Environmental Paradigm scale over the last 30 years: A meta-analysis. Journal of Environmental Psychology 30(2):143-158.

https://doi.org/10.1016/j.jenvp.2009.10.003

Henseler, J., Ringle, C.M., and Sinkovics, R.R. 2009. The use of partial least squares path modeling in international marketing. In: Sinkovics, R.R., and Ghauri, P.N., eds. New challenges to international marketing. Advances in International Marketing 20. Bingley, United Kingdom: Emerald Publishing. 277-319. https://doi.org/10.1108/S1474-7979(2009)0000020014

Homer, P.M., and Kahle, L.R. 1988. A structural equation test of the value-attitude-behavior hierarchy. Journal of Personality and Social Psychology 54(4):683-646.

https://doi.org/10.1037/0022-3514.54.4.638

Hongslo, E., and Lundberg, A.K.A. 2012. Regional planlegging i villreinområder - arealplanlegging som nytt virkemiddel? [Regional planning in wild reindeer areas - land use planning as a new instrument?]. Kart og Plan 4:255-265.
Jacobs, M.H. 2007. Wildlife value orientations in the Netherlands. Human Dimensions of Wildlife 12(5):359-365.

https://doi.org/10.1080/10871200701555345

Kaltenborn, B.P., Andersen, O., and Nellemann, C. 2009. Amenity development in the Norwegian mountains: Effects of second home owner environmental attitudes on preferences for alternative development options. Landscape and Urban Planning 91(4):195-201.

https://doi.org/10.1016/j.landurbplan.2009.01.001

Kaltenborn, B.P., Andersen, O., and Gundersen, V. 2014. The role of wild reindeer as a flagship species in new management models in Norway. Norsk Geografisk Tidsskrift - Norwegian Journal of Geography 68(3):168-177.

https://doi.org/10.1080/00291951.2014.904400

Klokov, K.B. 1997. Northern reindeer of Taymyr Okrug as the focus of economic activity: Contemporary problems of reindeer husbandry and the wild reindeer hunt. Polar Geography 21(4):233-271. https://doi.org/10.1080/10889379709377629

Kofinas, G., Osherenko, G., Klein, D., and Forbes, B. 2000. Research planning in the face of change: The human role in reindeer/caribou systems. Polar Research 19(1):3-21. https://doi.org/10.1111/j.1751-8369.2000.tb00323.x

Liang, H., Saraf, N., Hu, Q., and Xue, Y. 2007. Assimilation of enterprise systems: The effect of institutional pressures and the mediating role of top management. MIS Quarterly 31(1):59-87.

Manfredo, M.J. 2008. Who cares about wildlife? - Social science concepts for exploring human-wildlife relationships and conservation issues. New York: Springer. 228 p.

Manfredo, M.J., and Dayer, A.A. 2004. Concepts for exploring the social aspects of human-wildlife conflict in a global context. Human Dimensions of Wildlife 9(4):1-20. https://doi.org/10.1080/10871200490505765

Manfredo, M.J., Teel, T.L., and Henry, K.L. 2009. Linking society and environment: A multilevel model of shifting wildlife value orientations in the western United States. Social Science Quarterly 90(2):407-427. https://doi.org/10.1111/j.1540-6237.2009.00624.x

Milfont, T.L., and Duckitt, J. 2010. The environmental attitudes inventory: A valid and reliable measure to assess the structure of environmental attitudes. Journal of Environmental Psychology 30(1):80-94.

https://doi.org/10.1016/j.jenvp.2009.09.001

Miljøverndepartementet. 2005. Stortingsmelding nr. 21: Regjeringens miljøvernpolitikk og rikets miljøtilstand [Parliamentary Report No. 21: The Government's environmental policy and state of the environment].

Nellemann, C., Vistnes, I., Jordhøy, P., Strand, O., and Newton, A. 2003. Progressive impact of piecemeal infrastructure development on wild reindeer. Biological Conservation 113(2):307-317. https://doi.org/10.1016/S0006-3207(03)00048-X

Newsome, D., Dowling, R.K., and Moore, S.A. 2005. Wildlife tourism. Aspects of Tourism 24. Clevedon, United Kingdom: Channel View Publications. 298 p. 
Øian, H., and Skogen, K. 2016. Property and possession: Hunting tourism and the morality of landownership in rural Norway. Society \& Natural Resources 29(1):104-118. https://doi.org/10.1080/08941920.2015.1041658

Panzacchi, M., Van Moorter, B., Jordhøy, P., and Strand, O. 2013. Learning from the past to predict the future: Using archeological findings and GPS data to quantify reindeer sensitivity to anthropogenic disturbance in Norway. Landscape Ecology 28(5):847-859. https://doi.org/10.1007/s10980-012-9793-5

Raadik, J., and Cottrell, S. 2007. Wildlife value orientations: An Estonian case study. Human Dimensions of Wildlife 12(5):347-357. https://doi.org/10.1080/10871200701555378

Rodela, R. 2012. Advancing the deliberative turn in natural resource management: An analysis of discourses on the use of local resources. Journal of Environmental Management 96(1):26-34. https://doi.org/10.1016/j.jenvman.2011.10.013

Røed, K.H., Bjørnstad, G., Flagstad, Ø., Haanes, H., Hufthammer, A.K., Jordhøy, P., and Rosvold, J. 2014. Ancient DNA reveals prehistoric habitat fragmentation and recent domestic introgression into native wild reindeer. Conservation Genetics 15(5):1137-1149. https://doi.org/10.1007/s10592-014-0606-z

Rokeach, M. 1973. The nature of human values. New York: Free Press.

Sandström, C., Moen, J., Widmark, C., and Danell, Ö. 2006. Progressing toward co-management through collaborative learning: Forestry and reindeer husbandry in dialogue. International Journal of Biodiversity \& Management 2(4):326-333.

Schwartz, S.H. 1992. Universals in the content and structure of values: Theoretical advances and empirical tests in 20 countries. Advances in Experimental Social Psychology 25:1-65. https://doi.org/10.1016/S0065-2601(08)60281-6

Sjoholm, B. 2007. How the wild reindeer was tamed. The Antioch Review 65(2):362-372.
Sommerseth, I. 2011. Archaeology and the debate on the transition from reindeer hunting to pastoralism. Rangifer 31(1):111-128.

Stammler, F. 2007. Reindeer nomads meet the market: Culture, property and globalization at the 'End of the Land,' $2^{\text {nd }}$ ed. Berlin: Lit Verlag, Dr. W.Hopf. 369 p.

Strand, O., Gundersen, V., Panzacchi, M., Andersen, O., Falldorf, T., Andersen, R., Van Morter, B., Jordhøy, P., and Fangel, K. 2010. Ferdsel i villreinens leveområder [Human traffic in the wild reindeer ranges]. NINA Rapport 551. Trondheim: Norwegian Institute for Nature Research. 95 p.

Tanakanjana, N., and Saranet, S. 2007. Wildlife value orientations in Thailand: Preliminary findings. Human Dimensions of Wildlife 12(5):339-345. https://doi.org/10.1080/10871200701555519

Teel, T.L., Manfredo, M.J., and Stinchfield, H.M. 2007. The need and theoretical basis for exploring wildlife value orientations cross-culturally. Human Dimensions of Wildlife 12(5):297-305. https://doi.org/10.1080/10871200701555857

Tenenhaus, M., Esposito Vinzi, V., Chatelin, Y.-M., and Lauro, C. 2005. PLS path modeling. Computational Statistics \& Data Analysis 48(1):159-205. https://doi.org/10.1016/j.csda.2004.03.005

Vaske, J.J., Jacobs, M.H., and Sijtsma, M.T.J. 2011. Wildlife value orientations and demographics in The Netherlands. European Journal of Wildlife Research 57(6):1179-1187. https://doi.org/10.1007/s10344-011-0531-0

Vistnes, I., and Nellemann, C. 2008. The matter of spatial and temporal scales: A review of reindeer and caribou response to human activity. Polar Biology 31(4):399-407. https://doi.org/10.1007/s00300-007-0377-9

Vistnes, I., Nellemann, C., Jordhøy, P., and Strand, O. 2004. Effects of infrastructure on migration and range use of wild reindeer. Journal of Wildlife Management 68(1):101 - 108. https://doi.org/10.2193/0022-541X(2004)068[0101:EOIOMA]2 .0.CO;2

Vors, L.S., and Boyce, M.S. 2009. Global declines of caribou and reindeer. Global Change Biology 15(11):2626-2633. https://doi.org/10.1111/j.1365-2486.2009.01974.x

Zinn, H.C., and Shen, X.S. 2007. Wildlife value orientations in China. Human Dimensions of Wildlife 12(5):331 - 338. https://doi.org/10.1080/10871200701555444 